\title{
Self-Identification of Homestay Management Problems and Canvas Business Model
}

\author{
Majidah $^{1}$ \\ ${ }^{1}$ Departement of Accounting, School of Economics and Business, \\ Telkom University, Bandung, Indonesia \\ majidah@telkomuniversity.ac.id \\ Cahyaningsih $^{2 *}$, Rr Sri Saraswati ${ }^{3}$, Wahdan Arum Inawati ${ }^{4}$ \\ ${ }^{2,3,4}$ Department of Accounting, School of Economics and Business, \\ Telkom University, Bandung, Indonesia \\ cahyaningsih@telkomuniversity.ac.id, sassasuntung@telkomuniversity.ac.id, \\ wahdanaruminawati@telkomuniversity.ac.id
}

(Received April 08, 2021, accepted June 10, 2021)

\begin{abstract}
Laksana Village is in Ibun Sub-District, Bandung District. Geographically, Laksana Village is close to the Kamojang Tourism area, which is the leading tourism destination in Bandung District. The village has the potential for tourism development. To support the tourism development program, there are several homestays. However, it was found that many tourists spent the night outside the Laksana Village area. Another problem faced by homestay managers is the difficulty in determining homestay tariff. This Community Service (CS) activity aims to explore the problems faced by homestay managers through self-identification of problems using the Community Based Participatory Research method. The results of the selfidentification became the basis for the CS Team to map the nine elements of the canvas business model. The cost structure becomes a priority scale to be handled in order to solve the tariff determination problem and is expected to increase the value proposition. This CS activity specifically resulted in self-identification of problems and a business canvas model for homestay management.
\end{abstract}

Keywords: canvas business model and homestay; community based participatory research; self-identification of problems 


\section{Introduction}

Laksana Village is located in Ibun District, Bandung District, which is a tourist village and the Sundanese Village Development Master Plan (Department of Tourism \& Culture, 2017). Geographically, Laksana Village is close to the Kamojang Tourism area, which is the leading tourism destination in Bandung regency. The tourist areas include; (1) Kamojang Crater, (2) Geothermal tourism, (3) Eagle Conservation Tourism, (4) Ciharus Lake, and (5) Cimanuk Crater. Through the preservation of its cultural authenticity and supported by its geography, the village is potential for tourism development.

Other data showed that as many as $60 \%$ of the population of Laksana Village was included in productive age of 15-64 years (Coordinator of Statistics for Ibun Sub-District, 2018). Potential geographical condition for tourism development and the majority of the community who have productive age become the capital for the economic development of the community in the village. However, based on the results of the Focus Group discussion (FGD) with homestay managers, there was information that majority of tourists who visited the tourist area of Laksana Village did not spend the night at the homestay in the area and chose to spend the night outside the village, even though the following day Tourists were still continuing their tour in the area. Another problem that arose was that homestay managers had not been able to determine the cost of goods as the basis for determining the homestay rental tariff.

By referring to existing problems, then Strength, Weakness, Opportunity, and Threat (SWOT) analysis was carried out in order to explore the potential and empowerment opportunities for homestay management. SWOT analysis is a strategic plan to assess the internal conditions in the form of strengths and weaknesses as well as external conditions, namely opportunities and threats (Nasreen \& Afzal, 2020). Through the results of this analysis, the real conditions in Laksana Village were explored so as to implement the directed community service engagement (CSE) strategy. The results of Laksana Village SWOT analysis are shown in Table 1 below: 
Table 1. SWOT Analysis of Laksana Village

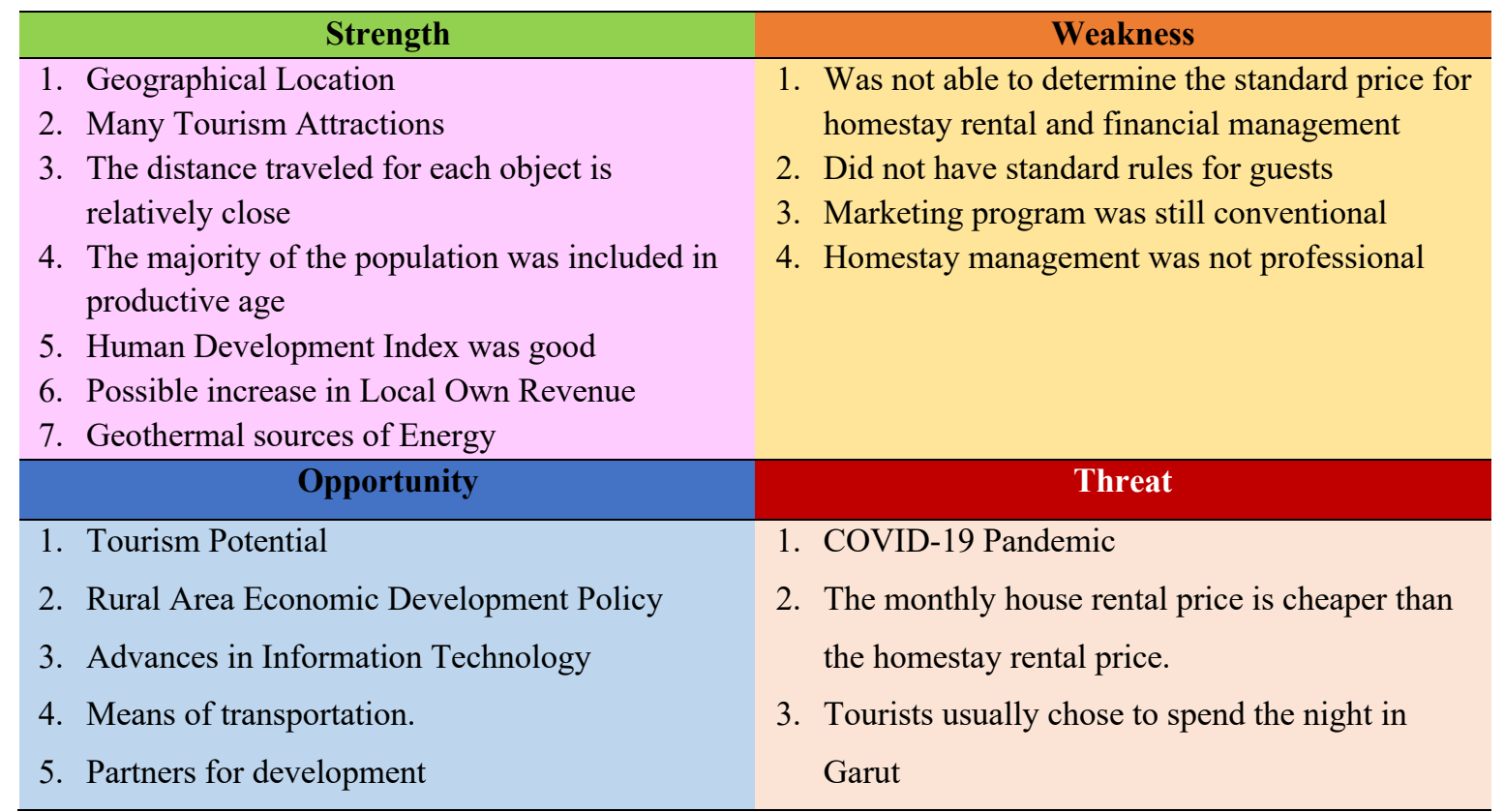

The results of the SWOT analysis showed that Laksana Village had several strengths as well as opportunities, thus the strategy that needs to be prepared should refer to SO. Strategies use strengths to minimize weaknesses, and take advantage of opportunities to anticipate threats. This SO strategy was used to explore the real problems they faced. Therefore, the current community service (CS) aims to encourage target partners or homestay managers to selfidentify the problems. Furthermore, the results were used by the CS Team to map the nine elements of the canvas business model to find out the priority scale need to be addressed first to develop a competitive and profitable homestay business.

\section{Methods}

The community service method used here was the Community Based Participatory Research (CBPR) method. It is a collaborative approach that involves target community, does not focus on formal arrangements, but provides opportunities for them to participate (Ansori et. al., 2021; Garcia, Rubin, \& Wallerstein, 2012). CBPR was implemented in the form of group discussion to identify self-identification of homestay management problems. This approach is expected to assist the implementation of CSE program according to the needs of the target community. The results of self-identification of problems were then used by the Facilitators or CS Team to solve the problems of homestay management through the canvas business model. Canvas business model is a management strategy in the form of a visual chart consisting of nine elements, 
namely customer segments, value propositions, channels, revenue streams, key resources, customer relationships, key activities, key partnerships and a cost structure to assist business planning (Haryanto, 2021). The implementation of CBPR continued with the preparation of nine elements of the canvas business model for homestay management can be observed in the following figure:

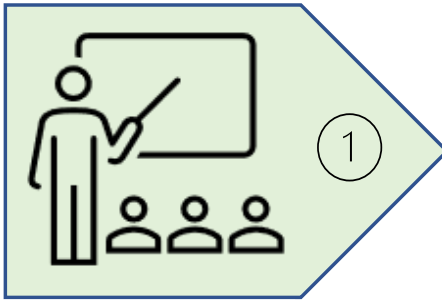

Explanation \& Direction

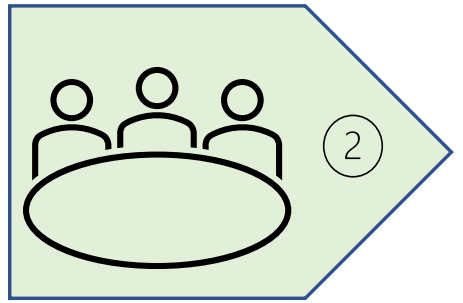

Group Discussion

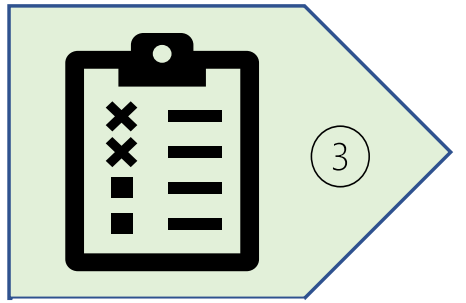

Recapitulation, Mapping $\&$ Analysis

Fig. 1. Implementation of community based participatory research and canvas business model

1) Explanation and Direction; the CS Facilitator Team assigned the homestay managers into several groups consisted of three people, respectively. Furthermore, the team provided explanation and directed them to identify the homestay management problems they faced (Community Based Participatory).

2) Group Discussion; each discussion group identified the homestay management problems they faced. Each group was facilitated with white cardboard, sticky notes and markers. Discussion was done by writing the problems encountered on the sticky notes and pasted them on the white cardboard provided.

3) Recapitulation, Mapping and Analysis; the results of the discussion from each group written on the notes and pasted on the white cardboard were collected and recapitulated by the CS Facilitator Team. The CS Facilitator Team grouped the similar problems together, so that the problems they identified as well as needs and role map became clear. The recapitulation was mapped based on the nine components of the canvas business model. Through this mapping, the priorities of CS program can be set according to the order of urgency of the problems.

\section{Results and Discussions}

\section{Results}

The results of the implementation of the CBPR method through self-identification of homestay management problems facilitated by group discussions are as shown in Figure 2 below. The 
discussion packaged in the form of a game made it easier to explore the real problems regarding homestay management they faced.

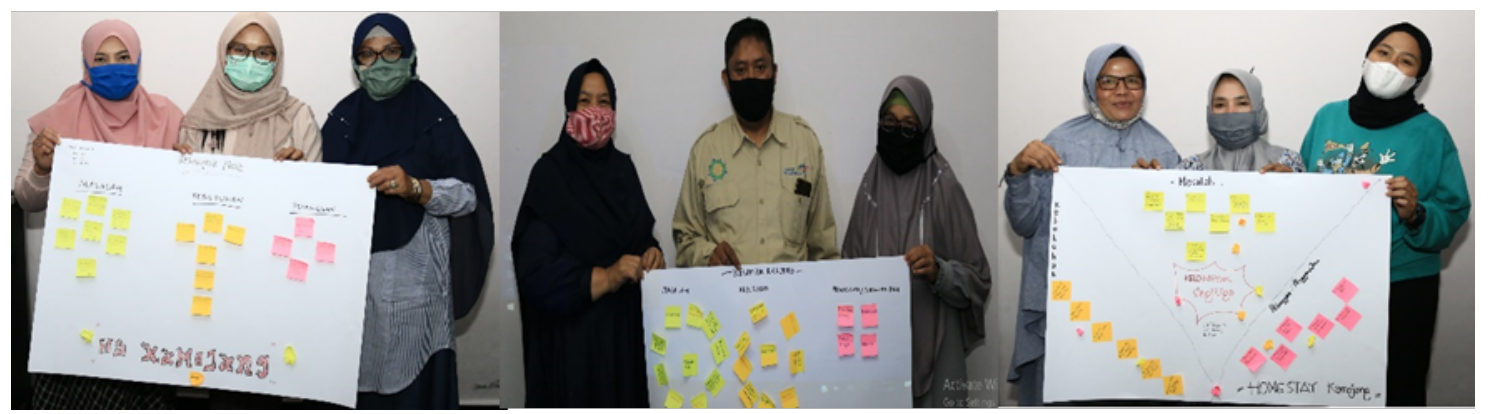

Fig. 2. Implementation of the CBPR method through self-identification of homestay management problems

The results of the self-identification of problems as shown in Figure 2, were recapitulated and a role map was compiled by the CS Facilitator Team as shown in the Table 2 as follows:

Table 2. Recapitulation of the results of self-identification of problems, needs, and role map of homestay management

\begin{tabular}{|c|c|c|c|c|}
\hline \multirow{2}{*}{ No } & \multirow{2}{*}{ Problem } & \multirow{2}{*}{ Need } & \multicolumn{2}{|c|}{ Role Map } \\
\hline & & & Tel-U Local Gov. & CSR-SOEs $\left.^{*}\right)$ \\
\hline 1. & $\begin{array}{l}\text { There was no standard } \\
\text { tariff }\end{array}$ & $\begin{array}{l}\text { Cost structure for determining } \\
\text { rental rates is required }\end{array}$ & & \\
\hline 2. & Difficulty in Promotions & $\begin{array}{l}\text { Content, Video Profiles \& } \\
\text { Promotion Media }\end{array}$ & & \\
\hline 3. & $\begin{array}{l}\text { Street Lights, Local } \\
\text { Maps \& Road Signs }\end{array}$ & $\begin{array}{l}\text { Street Lights, Local Maps \& } \\
\text { Road Signs }\end{array}$ & & \\
\hline 4. & Homestay Management & Standards of Budget Hotel & & \\
\hline 5. & $\begin{array}{l}\text { Lack of Coordination } \\
\text { with Local Governments }\end{array}$ & $\begin{array}{l}\text { There should be Coordination } \\
\text { with Local Governments }\end{array}$ & & \\
\hline 6. & There was no association & $\begin{array}{l}\text { Homestay Website management } \\
\text { organization is required }\end{array}$ & & \\
\hline
\end{tabular}

*) Corporate Social Responsibility of State-Owned Enterprises

Table 2 was compiled by the CS Facilitator Team based on self-identification of the problems became the basis for the facilitator team to map it into the nine elements of the canvas business model of homestay management. This canvas business model can guide towards a sustainable CSE program for homestay management. 


\section{Discussion}

The results of self-identification of homestay management problems as shown in Table 2 were used to map business strategies using the following nine elements of the canvas business model as follows:

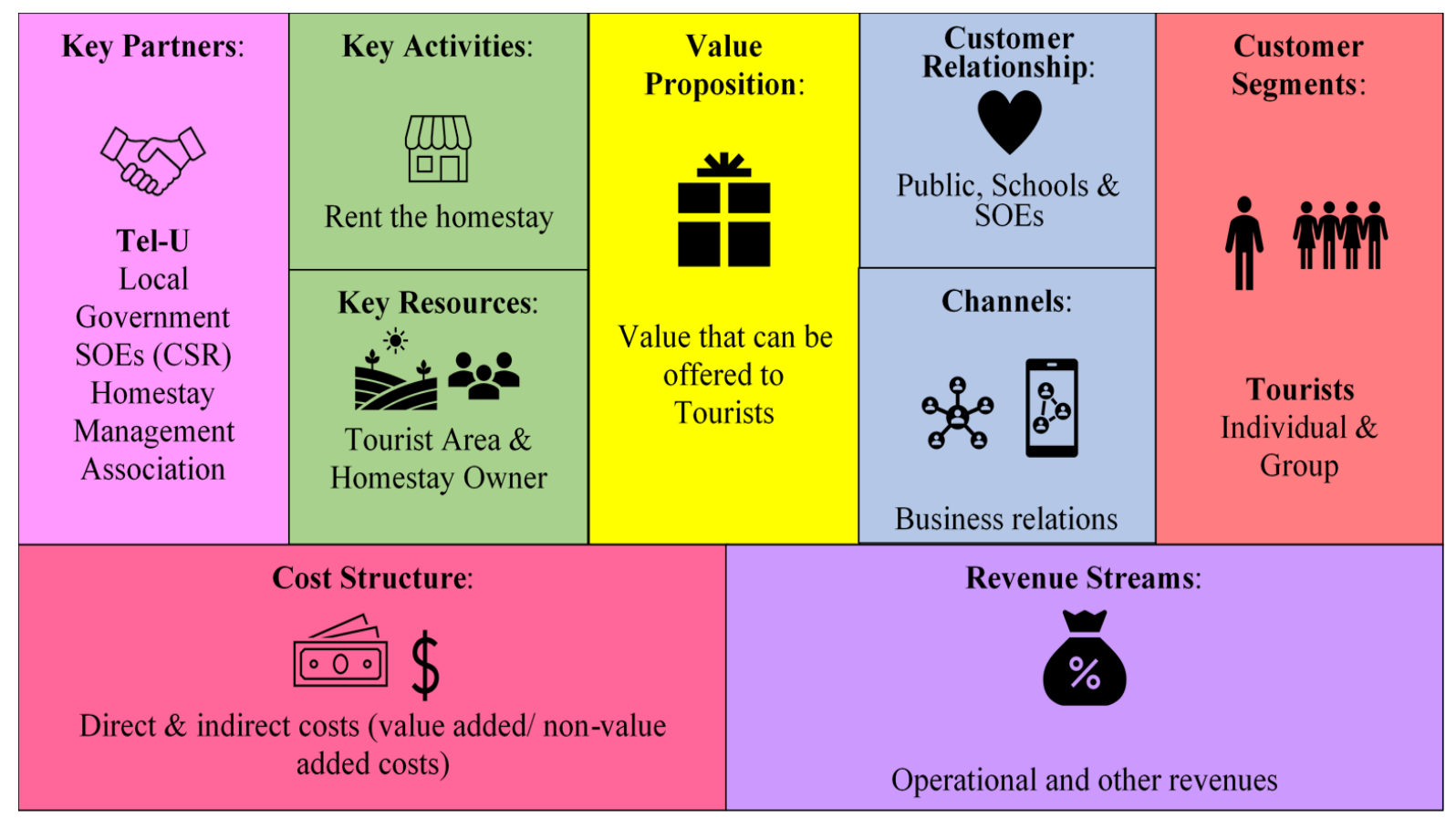

Fig. 3. Canvas business model mapping for Laksana Village Homestay management

The mapping of the canvas business model (Osterwalder, 2005; Mahdi \& Baga, 2018) regarding the homestay management in Laksana Village can be discussed as follows:

1) Customer Segments; the customer segments of homestays in Laksana Village are individual or group tourists (including students, university students, sports communities) as well as guests of SOEs operating in the tourist area of Laksana Village.

2) Value Proposition; the attraction or uniqueness of the homestays is the beautiful geographical location which is close to all tourist destinations including educational tours, namely the Java Eagle Conservation Center. If the condition of the area is managed properly, it will become a selling point.

3) Channels; business relations that can support homestay businesses, such as canteens, travel agents, transportation entrepreneurs, guest guides, regional arts managers and online promotion media managers. This business relationship has not been handled properly and in an integrated manner. 
4) Customer Relationship; homestay managers need to pay attention to relationships with their customers, both individual customers, and group customers through intermediaries, for example teachers who guide student activities, lecturers who supervise field study or practical work programs, SOE administrators who recommend their guests or place guests in homestays around Laksana Village as well as the sports community or other customers. Good relationship and service will make customers satisfied. Customer satisfaction can be a promotion media (Word of Mouth Marketing).

5) Key Activities; refer to activities related to the homestay. Homestay is an accommodation service business. Business activities related to service quality and commitment to the services offered and promised to customers must be fulfilled, as well as cleanliness.

6) Key Resources; Key resources are the main resources needed to run a business (Müller, 2019). Key resources consist of owners who are also homestay managers as well as the community wherein the homestay is located. Key resources can support the value proposition. To produce a value proposition, homestay managers need to have managerial skills through continuous coaching. Key Resources have not been fully addressed. Therefore, it is necessary to have a sustainable and structured CSE-Telkom University program for a certain period of time. Likewise, the support of Partners and Village Officials in preserving the environment by highlighting local wisdom is needed.

7) Key Partners; the meaning of key partner varies according to the type of business managed. In relation to homestay management, key partners consist of Local Government, SOEs through the Corporate Social Responsibility (CSR) program, homestay management associations and Telkom University CSE Program Facilitators, namely Lecturers who carry out community service programs for homestay managers. The role of Key Partners can develop Key resources and increase the value proposition.

8) Cost Structure; the cost structure depends on the business character (Holtström, Bjellerup, \& Eriksson, 2019). Homestay cost structure consists of direct and indirect costs. Cost structure reflects the financial consequences of an entity's business model (Osterwalder \& Pigneur, 2010; Müller, 2019). Cost structure is an important factor for determining homestay tariff. In the case of homestays in Laksana village, the cost structure became a priority scale since it is related to the main problem in homestay management, namely the determination of homestay tariff. Homestay managers were asked to write down the types of costs incurred in the form provided by the facilitator in order to compile the cost structure. The cost structure is useful for determining the standard homestay rental tariff, so that it can 
be the basis for decisions made by homestay managers to determine the profit limits they expect. Cost Structure efficiency can increase the value proposition.

9) Revenue Streams; refer to the revenues earned from the homestay within a certain period of time. The income earned needs to be set aside for business development and needs. Homestay income can be increased through other income in collaboration with canteen entrepreneurs. These types of other income include consignment income from products to be sold at homestays and income from commission (channels). Revenue Stream is also related to the value experienced by consumers (Gaiardelli \& Songini, 2020), because companies earn additional income by providing goods or services through cooperation with other parties (providers of goods or services) for tourists who stay at the homestay.

The nine components of the canvas business model were arranged according to the characteristics of the homestay business in Laksana Village. The nine components served as a guide for the facilitator team to implement the CSE program for homestay managers in a sustainable manner for homestay development.

\section{Conclusion}

By referring to the introduction and discussion, it can be concluded as follows:

1) Self-identification of problems reflects the participation of target community to address the problems they faced in managing homestay. Therefore, the appropriate CS method is Community Based Participatory Research (CBPR).

2) CBPR also explained the collaboration of target community with the CS Facilitator Team; The results of self-identification of problems were recapitulated well by the CS Facilitator Team, so that the problems and needs of the homestay as well as a map of the roles of stakeholders can be identified.

3) The mapping of the nine elements of the canvas business model was prepared based on the results of self-identification of homestay management problems. The cost structure was a priority for handling the main problem, namely the determination of homestay rental tariff.

4) The nine elements of the canvas business model set specifically for homestay became the guide for the sustainable CE program and purposeful development of the homestay business. These nine canvas business models are expected to generate several revenue streams in addition to the homestay business, so that it can increase the value proposition. 


\section{Recommendations}

Based on the conclusions, several recommendations can be proposed as follows:

1) For lecturers or community service program facilitators; it is recommended to apply the CBSR method to encourage the participation of target community, so that the implementation of the CS program is in accordance with the problems and needs of the target community.

2) For CSE Facilitator-Telkom University; the results of the mapping of the canvas business model through its nine components can be the basis for reference and evaluation of the sustainable CSE program for homestay managers.

3) For Homestay Managers; with the guidance of CE Facilitators, they need to develop a cost structure first to determine competitive and efficient homestay tariff.

4) For Telkom University; this CSE activity can be used as input on the roadmap for the Directorate of Research and Community Service of Telkom University, especially for the development of Laksana Village as Telkom University's Assisted Village.

5) For local government and SOEs; the mapping of the nine canvas business models for homestay management can be a reference for local governments and SOEs to carry out their work programs towards tourism villages in accordance with corporate social responsibility.

\section{Acknowledgements}

This Community Service Engagement (CSE) Program can be implemented with the direction and financial support provided by the Directorate of Research and Community Service of Telkom University. Furthermore, we would like to express our gratitude to the Village Officials and CSE Target Partners, namely the homestay managers.

\section{References}

Ansori, M., Afandi, A., Fitriyah, R. D., Syafriani, R., \& Farisia, H. (2021). PendekatanPendekatan dalam University Community Engangement. Surabaya: UIN Sunan Ampel Press.

Badan Statistik Kabupaten Bandung. (2020, November 4). Badan Statistik Ka. Bandung. Retrieved from BPS.: https://bandungkab.bps.go.id.

Dinas Pariwisata \& Kebudayaan, P. (2017). Masterplan Pengembangan Kampung Sunda Kacamatan Ibun. Bandung. 
Gaiardelli, P., \& Songini, L. (2020). Successful Business Models for Service Sentres: An Empirical Analysis. International Journal of Productivity and Performance Management, 1-25.

Garcia, A. P., Rubin, V., \& Wallerstein, N. (2012). Community-Based Participatory Research: A Strategy for Building Healthy Communitiesand Promoting Health through Policy Change. California: www.policylink.org.

Haryanto, A. (2021, Januari 23). Business Model Canvas: Pengertian, Tujuan dan Manfaatnya. Retrieved from Jojonomic: https://www.jojonomic.com/blog/business-model-canvas.

Holtström, J., Bjellerup, C., \& Eriksson, J. (2019). Business Model Development Forsustainable Apparel Consumption. Journal of Strategy and Management, 12 (4), 481-504.

Mahdi, A. F., \& Baga, L. M. (2018). Business Model Canvas Perusahaan Pengelolaan Rumput laut. Forum Agribisnis, 8(1), 1-16.

Müller, J. M. (2019). Business Model Innovation in Small- and Medium-Sized Enterprises. Journal of ManufacturingTechnology Management, 30(8), 1127-1142.

Nasreen, K., \& Afzal, M. T. (2020). Strenght, Weaknesess, Opportunities and Threath in Higher Education: A Swot Analisys of Allama Iqbal Open University Islamabad (Pakistan). Asian Association of Open Universities Journal, 15(3), 321-333. Retrieved from http://doi.org/10.1108/aaouj-11-2019-0052.

Osterwalder, A. (2005, November 5). Retrieved from Business Model Design and Innovation: https://web.archive.org.

Osterwalder, A., \& Pigneur, Y. (2010). Business Model Generation. A Handbook for Visionaries, Game Changers, and Challengers. Wiley. 